\title{
CEREALS AS GUARANTOR OF FOOD SOVEREIGNTY
}

\section{PAATA KOGUASHVILI}

Doctor of Economic Science, Professor

Georgian Technical University, Academician of the Georgian Academy of Agricultural Sciences, Georgia

paata_koguashvili@hotmail.com

\section{NIKOLOZ CHIKHLADZE}

Doctor of Economic Science, Doctor of Theology, Professor

Kutaisi University, Akaki Tsereteli State University, Georgia

nikoloz.chikhladze@unik.edu.ge

\begin{abstract}
"We just have to try to produce as much bread as we need, so, we never would need to buy it, enough for local market"
\end{abstract}

Ilia Chavchavadze

KEYWORDS: WHEAT, STATE PROGRAM, FOOD, EFFICIENCY, IMPORT.

For citation: Koguashvili, P., Chikhladze, N. (2019). Cereals as Guarantor of Food Sovereignty, Globalization And Business, №8, pp. 54-59. https://doi.org/10.35945/gb.2019.08.005

\section{INTRODUCTION}

The problem of grain economy is one of the central issues in any country with a highly developed economy. This should not be surprising, since cereals are the only basis for the production of bread and bakery products, meat and meat products, milk and dairy products, eggs and other basic products.

The Georgian people have known wheat since the Eneolithic Period and they had already grown several varieties of wheat ("Ifkli", "Asli", "Dika”, "Makha", "Zanduri”, "Doli”, and "Khulogo"). The people of no other country have such differentiated names of wheat varieties, which proves that the Georgian people had played an important role in the formation of wheat crops varieties. In the view of academician N. Vavilov, Georgia occupies a special place in the appearance of the wheat forms (Koguashvili, 2013:38).

Up today, 23 cultivated and 4 wild-growing varieties of wheat have been listed and registered in the botanical genus worldwide. Of these, 14 cultivated varieties are represented in Georgia. In addition, four more species of Georgian wheat have been obtained, which taken together, account for $65 \%$ of wheat varieties belonging to the botanical genus of wheat. More than 150 varieties and species (up to 160) are described among Georgian cultural wheat species. Georgia's biogeoclimatic diversity, as well as the diligence of Georgian man, his creative ability and people's selection have contributed to their appearance and formation. The Georgian nation has a large historical experience in wheat cultivation. (Naskidashvili, 1992:30).

\section{FOOD PROBLEM AND GEORGIA IN THE CONTEXT OF CEREAL PRODUCTION}

Many international organizations, respected journals, or distinguished scientists and specialists being close to food problems have repeatedly warned the entire world of the danger of increased food insecurity in the immediate future. In particular, just at the end of the last century, the Food and Agriculture Organization (FAO) of the United Nations published the projection that the planet's population demand for food would increase by $50 \%$ in $2015-2020$, leading to an extreme food crisis.

This official announcement should send a strong message to food-importing developing countries, since the negative effects of a global food crisis are usually reflected primarily on the poor people in such countries.

In the last two decades, there has been a trend towards the decline in world cereal output and the continuing rise in their prices. The latter is also due to the fact that population growth has far outpaced the per capita growth of cereal production.

In the last four decades, the global price of 1 ton of wheat has increased from $\$ 80.4$ to $\$ 173.4$. The era of cheap food in the world has come to an end.

Table 1. The global price of wheat in 1980-2019 (USD)

\begin{tabular}{|c|c|c|}
\hline Period & bushel & ton \\
\hline 1980,15, XII & 4.91 & 80,4 \\
\hline 1990,10, XII & 2.66 & 97,7 \\
\hline 2000,4, XII & 2.74 & 100,7 \\
\hline 2010,27, XII & 7.94 & 291,7 \\
\hline 2015,21, XII & 4.68 & 171,9 \\
\hline 2016,5 XII & 4.16 & 152,8 \\
\hline 2017,18, XII & 4.25 & 156,1 \\
\hline 2018,24, XII & 5.12 & 188,1 \\
\hline 2019,13 VIII & 4.72 & 173,4 \\
\hline
\end{tabular}

Source: https://www.macrotrends.net/2534/wheat-prices-historical-chart-data 
That is why cereals, as strategic goods, are not only the principal guarantee of economic independence for each country, but also a powerful tool for political influence on cereals-importing countries (Koghuashvili, 2004: 23). If we add to this unoptimistic forecast made by FAO of growing and supplying cereals, we can assume that the "food and political cost" of cereals will grow even more in the future. According to this organization, in 2018, the global output of wheat was 736.1 million tons, which is $2.7 \%$ less than in the preceding year. Unfavorable climate conditions, especially in the CIS countries, are the main cause of this decline, which will be partially offset by a slight increase in South and North America. In 2019, wheat production in Russia declined by 10 million tons, the average hectare yield fell from 1.9 tons in 2018 to 1.5 tons, while in Kazakhstan the same indicator fell to 0.7 tons. The increased demand for wheat, under conditions of its decline, by the end of 2019 will result in a 3.3\% drop in world grain stocks (FAO, 2018).

As is well known, most of world grain stocks are owned by only a few States. These include the US, Canada and EU countries. Of these countries, prominent is the United States, which accounts for $5 \%$ of the world population and $47-50 \%$ of grain stocks. This is at a time when there are about 120 countries that are engaged in the import of cereals throughout the world. Therefore, it is easy to imagine the situation of countries dependent on the imports of cereals, including Georgia, in the event of food crisis. The first notable symptoms in this regard had been already observed. In particular, agricultural policies in Western countries have recently been revised, which is reflected, on the one hand, in the reduction of state subsidies to farmers, and on the other hand, in weakening measures aimed at protecting the domestic markets from foreign competition. This policy has already been legally reflected in the so-called "Uruguay and Doha Round" documents of the World Trade Organization.

In this context, of particular interest is the position of the FAO and the European Union regarding developing countries, incuding on the import of wheat. It is noteworthy that the attitude of these reputable organizations in this regard is extremely and categorically negative. They recognize that the subsidy system for farmers in the highly developed economies of the West helps the relatively poor importing countries in making the import cheaper, but low food prices, including cereals, in many developing countries make them deny their own production, which ultimately results in reduced food production in the world and an inevitable rise in food prices.

Owing to the current situation, countries having appropriate land resources, based on the generally recognized principles of food self-sufficiency, spared no effort in their action to develop grain economy, regardless of whether they have the relative or absolute advantages of cereals production. It is a fact that with an acceleration of "biologization" of agricultural production, delivery of cereals to the global market will be further reduced, which will further increase their prices.

It needs to be well understood that the world faces growing numbers of hungry people every year, and thus, there is a need to put into use all the reserves for increasing cereal production locally to avoid the further exacerbation of this problem.

In the modern world, two basic criteria for food security are recognized, and both are related to cereals. These include the emergency grain stocks and the volume of cereal production in per capita terms. The first provides the necessary safeguards and reliability in case of emergencies, and the second one shows the degree and level of country's dependency on the import of cereals (based on the physiological standards of consumption of bakery products in the country).

However, it is generally accepted that the emergency stocks include the transient cereal production sufficient to guarantee the national food supply for 55-60 calendar days, or $17-18 \%$ of demand (of course, it would be welcome if the Government created more stock).

In Georgia, both maize and wheat are of vital importance, but it has long been regarded as one of the exemplary countries in wheat production and consumption.

Independence was accompanied by the annihilation of practice of centralized supply of cereals from the so-called "Union funds", due to which, in Georgia, there had ceased operation enterprises for the production of mixed feed, poultry plants, specialized meat and dairy units, and so on. As a result, there has been a dramatic drop in the livestock production, which has had a serious impact on the deterioration of the population's standard of living. In particular, per capita consumption of these products has declined sharply, the food ration structure has deteriorated, and so on.

Unfortunately, Georgia, as a food-producing country, has lost these positions over the last 50 years. The following statistics confirms this. In 1950, Georgia produced 786,000 tons of cereals, or $223 \mathrm{~kg}$ per capita (the population in that period was 3.5 million). By 1980, Georgia's population had exceeded 5 million, producing $121 \mathrm{~kg}$ of cereals per capita (the picture remained virtually unchanged over the next ten years. In 1990, Georgia's population was 5.4 million and $121 \mathrm{~kg}$ of cereal was still produced). Cereal production increased from 150 to $155 \mathrm{~kg}$ per capita in 2000-2003, but it happened only due to population decline - in this period, the population was declined by 1 million (in the structure of cereals, maize occupies the first place and the second place is occupied by wheat. On average, they account for $90 \%$ of the total cereals, while the remaining $10 \%$ are barley, oats, etc.).

Thus, under real conditions, a very difficult situation has arisen: wheat per capita production in 2018 is 7.8 times lower than in 1950, 4.2 times lower than in 1980, and 5.4 times lower than in 2003 (see Table 2).

\section{THE POSSIBILITIES OF INCREASING CEREAL PRODUCTION}

The analysis of the above trends and data allows us for concluding that Georgia, like many countries in the world, is potentially at food insecurity risks. There is no doubt that there is a severe deficit in the balance of production and consumption of wheat, due to which, effective demand for it should be met by imports, that is, the danger is obvious from 
Table 2. Cereal production in Georgia in 2010-2018

\begin{tabular}{|c|c|c|c|}
\hline & 2010 & 2015 & 2018 \\
\hline $\begin{array}{l}\text { Mid year population, thousand } \\
\text { people }\end{array}$ & 3786.7 & 3725.3 & 3726.5 \\
\hline $\begin{array}{c}\text { Cereal production (wheat, barley, } \\
\text { oats, maize), thousand tons }\end{array}$ & 214.8 & 356.2 & 363.7 \\
\hline \multicolumn{4}{|l|}{ Including: } \\
\hline Wheat & 48.4 & 125.6 & 107.1 \\
\hline Maize & 141.1 & 184.6 & 194.2 \\
\hline \multicolumn{4}{|l|}{$\begin{array}{l}\text { The share of cereals in overall pro- } \\
\text { duction }\end{array}$} \\
\hline - wheat & 22,5 & 35,3 & 29,4 \\
\hline - $\quad$ maize & 65,7 & 51,8 & 53,4 \\
\hline Cereal per capita production, kg & 56,7 & 95,6 & 97,6 \\
\hline \multicolumn{4}{|l|}{ Including: } \\
\hline wheat & 12,8 & 33,7 & 28,7 \\
\hline maize & 37,3 & 49,6 & 52,1 \\
\hline \multicolumn{4}{|l|}{ Self-sufficiency rate, \%: } \\
\hline - $\quad$ with wheat & 6 & 17 & 15 \\
\hline - $\quad$ with maize & 96 & 77 & 71 \\
\hline
\end{tabular}

Source: compiled on the basis of data of National Statistics Office

both a socioeconomic and political points of views. In such a situation, Georgia becomes objectively dependent on one or another country realizing import or carrying out humanitarian activities through a some kind of profit.

It is estimated that the country needs 1500-1700 thousand tons of cereals annually, of which 780 thousand tons should be directly used for food purposes. In terms of the bread and bakery products, this volume is $680-690$ thousand tons, which requires 525-530 thousand tons of flour. Then, from locally produced wheat, it is possible to produce 120-140 thousand tons of flour (140-150 thousand tons on average, based on the commercial wheat production). The remaining part is to be imported (see Table 3 ).

Table. Import of cereals in Georgia in 2008-2018 (million USD)

\begin{tabular}{|l|c|c|c|}
\hline Year & Cerelas, - total & $\begin{array}{c}\text { including } \\
\text { wheat }\end{array}$ & $\begin{array}{c}\text { the share of wheat in } \\
\text { the import of cereals, } \\
\%\end{array}$ \\
\hline 2008 & 113,3613 & 108,8517 & 96,0 \\
\hline 2009 & 113,4271 & 105,0602 & 92,6 \\
\hline 2010 & 179,0637 & 174,0547 & 97,2 \\
\hline 2011 & 196,5481 & 184,2322 & 93,7 \\
\hline 2012 & 249,6049 & 239,9502 & 96,1 \\
\hline 2013 & 203,5139 & 184,836 & 90,8 \\
\hline 2014 & 167,0969 & 151,7578 & 90,8 \\
\hline 2015 & 134,5381 & 119,3524 & 88,7 \\
\hline 2016 & 100,0621 & 86,0615 & 86,0 \\
\hline 2017 & 114,5025 & 98,175 & 85,7 \\
\hline 2018 & 132,8005 & 114,9037 & 86,5 \\
\hline
\end{tabular}

Source: National Statistics Office - www.geostat.ge

It is obvious that per capita cereal production it has been systematically declining, while of bread and bread products consumption significantly exceeds the country's physiological standard (instead of standard 350 grams, a significant portion of the population actually consumes $420-450$ grams, which should be explained by the unaffordability of other products).

The provision of assistance to the target population, under conditions of rising food prices, should be based not on food subsidies for them (that is artificial reduction of food prices), but on increasing their income. Although the growth of people's income may not always equal to the rise in food prices, this applies to different population groups in different ways. The poor people in the poor countries have the direct prospect in this regard (the proportion of the population living below the poverty line in Georgia is $20.1 \%$, while the Gini coefficient is 0.37). (National Statistics Office, 2019). The outcome of this process for all countries will depend on the quality of State policy. Those who have the worst agrarian policies will be the losers.

Most scientists and specialists agree that the transformation of agricultural lands allows for increasing the harvest area for cereal in the country by 150 thousand hectares, or to 350 thousand hectares. Such a structural transformation of arable lands allows for producing 1.0-1.1 million tons of cereals in the medium term in Georgia, which is sufficient for the country's food security (according to the adequacy ratio). As to wheat, we can produce it within $60-65 \%$ of our demand.

Calculations made on the basis of the technology roadmaps of the I. Lomouri Institute of Arable Farming and the Production Association "Lomtagora" show that the value of 1 ton of wheat produced in Georgia will be \$25-30 less as compared to imported wheat.

Given the shortage of arable land in our country, in the future, the emphasis should be mainly placed on the intensive factors of increasing yields of cereals. The introduction of intensive (high-yield) varieties of wheat and maize will allow us for producing on average 4 tons of wheat and 8 tons of maize per hectare, in the perspective.

Georgia has considerable stocks reserves due to the increased relclamed land areas, recconstruction of the existing land-reclamation systems, their technical modernization and enhancing the sustainability of water supply. Important measures must be taken to strengthen grain enterprises, as the material-technical base of this sector, in terms of soil protection, agrochemical services and improving soil fertility. In this regard, of special importance are the measures for cultivation of salt-affected and alkaline soils existing in the country and transforming them into agricultural areas (their total area exceeds 210 thousand hectares).

Application of aforementioned stocks and substantial increase in cereal production will only be possible if all the available levers and means of material-economic incentive of its production will be used, in which the State has a crucial role to play.

Stimulation of cereal production can be realized in different ways. In particular, exemption of cereal crops from taxation. There may also be used the state guaranteed purchase of cereals produced, concessional credit systems, insurance systems, direct subsidies (this will not be a violation of the obligations to the World Trade Organization, since, in accordance with the Charter of this organization, the country can 
direct $5 \%$ of export earnings to subsidize the important sectors), and so on.

One of the major problems of the grain economy development is protection of the consumer market. Frequently, the well-packaged, but low-quality and cheap products from different countries reach the consumer market, which are intended for our population with low paying capacity. The products reached the market in this way, can affect negatively the country's economy in many aspects. First, it may cause damage to life and health of its immediate consumers, and then to the country's budget in general. We mean not the direct losses (tax evasion, etc.), but losses resulting from the creation of an unfavorable business environment for local entrepreneurs.

It is indisputable that our cereal producers face the problem with selling the produced cereals every year. The existence of cheap and low-quality products in the market frequently forces them to sell cereals for the very low prices, to suffer considerable losses and subsequently to withdraw this business altogether. In this situation, there is an increasing number of uncultivated arable lands and unemployed persons, the amount of foreign currency flowing out of the country and the degree of the country's dependency on the import of cereals grain, with all its negative effects.

There are about 180 grain processing plants in Georgia with small and large production capacity, with a total production capacity of 6500 tons per day. Of these, 16 large en- terprises have a total capacity of more than 3500 tons per day. Today, these capacities are utilized only minimally - at $10-15 \%$, which in turn causes economic and social problems.

One of the key areas for resolving this problem, first of all, should be considered the changes in the country's agricultural policy and bringing it into line with the global challenges. It is about the national economy, which is going through the period of acute crisis, as well as goods producer who has no incentive to work.

\section{FORECAST}

Economic calculations indicate that by 2025 , the optimal area for wheat will be considered: 114.0 thousand ha, for crops - 421.8 thousand tons*, for a grain-storing - 120.0 thousand ha, and for a fodder - 50.0 thousand ha, for maize - 170,0 thousand ha and 714,0 thousand tons, for barley 50,0 thousand ha and 160,0 thousand tons, for oats - 20,0 thousand ha and 50,0 thousand tons (see Tables 4 and 5). In case of land consolidation, the wheat cultivation area may be increased to 150.0 thousand hectares.

A country with favorable biogeoclimatic conditions for increasing cereal production, its cultivation skills and traditions, cereal processing capacities, and the local market should not be entirely dependent on imports from other countries.

Table 4. Agricultural crops production areas (thousand ha) (optimized, 2025) (Keshelashvili, Koguashvili, 2017:45)

\begin{tabular}{|c|c|c|c|c|c|c|c|c|c|c|c|}
\hline \multirow[b]{2}{*}{ Agricultural crops } & \multirow[b]{2}{*}{$\begin{array}{l}\frac{\pi}{0} \\
\overline{00} \\
\stackrel{0}{0}\end{array}$} & \multicolumn{10}{|c|}{ Including regions } \\
\hline & & $\frac{\frac{\pi}{0}}{\frac{\pi}{2}}$ & 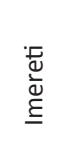 & 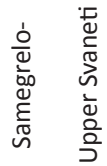 & 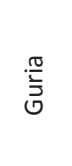 & 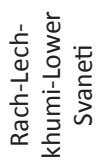 & 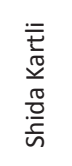 & 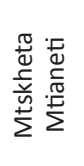 & 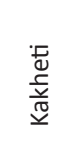 & 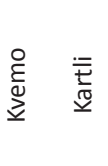 & 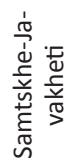 \\
\hline Total areas & 625 & 9,2 & 80,6 & 70,7 & 19,1 & 7,0 & 62,6 & 35,8 & 155,0 & 121,6 & 63,4 \\
\hline Wheat & 114 & - & 0,7 & - & - & - & 26,3 & 5,3 & 52,2 & 23,0 & 6,5 \\
\hline $\begin{array}{c}\text { Maize and grain-storing } \\
\text { and fodder crops }\end{array}$ & 170 & 4,0 & 53,3 & 51,8 & 11,2 & 3,5 & 4,7 & 6,5 & 16,8 & 15,4 & 2,8 \\
\hline Lobio & 13 & 0,12 & 0,5 & 0,3 & 0,06 & 0,02 & 3,8 & 3,8 & 2,8 & 1,0 & 0,6 \\
\hline Sunflower & 15 & - & - & - & - & - & 0,08 & 0,8 & 13,2 & 0,82 & 0.1 \\
\hline
\end{tabular}

Table 5. The volumes of agricultural production output (thousand tons) (optimized, 2025)

\begin{tabular}{|c|c|c|c|c|c|c|c|c|c|c|c|}
\hline \multirow[b]{2}{*}{ Agricultural crops } & \multirow[b]{2}{*}{$\begin{array}{l}\frac{\pi}{00} \\
\frac{0}{0} \\
0\end{array}$} & \multicolumn{10}{|c|}{ Including regions } \\
\hline & & $\frac{\frac{\pi}{0}}{\frac{\pi}{0}}$ & 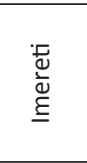 & 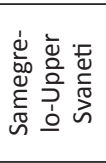 & 茜 & 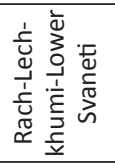 & $\begin{array}{l}\frac{\bar{y}}{\frac{\pi}{\pi}} \\
\frac{0}{\pi} \\
\frac{\pi}{0} \\
\frac{0}{n}\end{array}$ & 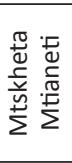 & 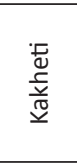 & 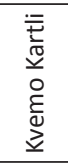 & 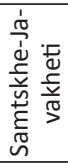 \\
\hline Wheat & 421,8 & - & 2,6 & - & - & - & 97,3 & 19,6 & 193,1 & 85,1 & 24,1 \\
\hline Barley & 160,0 & - & 0,2 & - & - & - & 26,4 & 5,2 & 23,0 & 32,2 & 73,0 \\
\hline Oats & 50,0 & - & - & - & - & - & 3,0 & 4,8 & 24,8 & 13,2 & 4,2 \\
\hline $\begin{array}{l}\text { Maize and grain-storing and } \\
\text { fodder crops }\end{array}$ & 714,0 & 16,8 & 223,8 & 217,6 & 47 & 14,7 & 19,7 & 27,3 & 70,6 & 64,7 & 11,8 \\
\hline Lobio & 14,05 & 0,3 & 0,9 & 0,5 & 0,2 & 0,05 & 2,0 & 2,6 & 4,7 & 1,7 & 1,1 \\
\hline Rye & 5,4 & - & - & - & - & - & - & - & - & 3,0 & 2,4 \\
\hline Sunflower & 22,0 & - & - & - & - & - & 0,1 & 1,2 & 19,4 & 1,2 & 0,1 \\
\hline Soybean & 12,0 & - & 3,8 & 7,7 & 0,1 & - & 0,4 & - & - & - & - \\
\hline
\end{tabular}

\footnotetext{
${ }^{*}$ High-yield crop, such as Triticale, which has been tested in Georgia, can also be used as animal food in livestock production
} 


\section{CONCLUSION}

In order to avoid the long-standing problem, it is necessary to apply all the reserves for increasing domestic cereal production, for which, first of all, Georgia should adopt a financially, technically, technologically and institutionally strong State program supporting grain producers, which will also involve institutional measures to produce elite seeds.

We believe that grain and the production of cereals as a strategic food, must be considered a priority both in the medium and the long term (as well as the production of own seeds, saplings, livestock and other agricultural products). This is required by an objective reality created in the world food production, Georgia's overall economic interests, and the goal to ensure food security.

One of the key areas for resolving this problem, first of all, should be considered the changes in the country's agricultural policy and bringing it into line with the global challeng- es. It is about the national economy, which is going through the period of acute crisis, as well as goods producer who has no incentive to work. In addition, it is necessary to adopt laws - "On Food Security of Georgia", "On Protection and Sustainable Development of Agricultural Sector of Georgia", etc., which must become some kind of guidance for a revival agricultural production and solving the food problem. Only the Government can cope with this problem. It is clear from the above-stated that:

- Food security is one of the top priorities for the country and the State;

- A government responsibility and the degree and direction of its intervention in the agri-food processes are crucial factors in saving the country from famine.

There is no way the country with such potential is a beggar State, when it has every possibility to increase wheat production. This is necessary in view of the current reality and the geopolitical situation.

\section{REFERENCES:}

1. Koguashvili P. (2013) Ilia Chavchavadze. Through the eyes of a business manager. Tbilisi: "MERIDIANI publishers, p. 38.

2. Naskidashvili P. (1992) Genetic and selective values of Georgia wheat. Journal "Agro-Bulletin of Georgian Academy of Agricultural Sciences", No. 1, p. 30. Koguashvili P. (2004) Georgia's food security: realities and projections. Tbilisi, "KOLORI" publishers, p. 23.

3. FAO (2018) Food outlook, July. URL: http://www.fao.org/3/CA0910RU/ca0910ru.pdf

4. National Statistics Office (2019) URL:https://www.geostat.ge/ka/modules/categories/192/tskhovrebis-done

5. Keshelashvili O., Koguashvili P. (2017) Projected growth of agricultural sector of Georgia. Tbilisi, SAARI” publishers, p. 45. 


\title{
CEREALS AS GUARANTOR OF FOOD SOVEREIGNTY
}

\author{
PAATA KOGUASHVILI \\ Doctor of Economic Science, Professor \\ Georgian Technical University, \\ Academician of the Georgian Academy of Agricultural Sciences, Georgia \\ paata_koguashvili@hotmail.com

\section{NIKOLOZ CHIKHLADZE} \\ Doctor of Economic Science, Doctor of Theology, Professor \\ Kutaisi University, Akaki Tsereteli State University, Georgia \\ nikoloz.chikhladze@unik.edu.ge
}

"We just have to try to produce as much bread as we need, so, we never would need to buy it, enough for local market"

Ilia Chavchavadze

\section{KEYWORDS: WHEAT, STATE PROGRAM, FOOD, EFFICIENCY, IMPORT.}

For citation: Koguashvili, P., Chikhladze, N. (2019). Cereals as Guarantor of Food Sovereignty, Globalization And Business, №8, pp. 54-59. https://doi.org/10.35945/gb.2019.08.005

\section{SUMMARY}

Georgia has long been considered one of the exemplary wheat producing and consuming countries. In the article, the authors claim that the production of cereals as a strategic food must be a priority, and that the structural transformation of arable lands will allow for producing 1.0-1.1 million tons of cereals in the medium term, which is sufficient for the country's food security. As to wheat, we can produce it within $60-65 \%$ of our demand, of which, price of one ton will be $\$ 25-30$ as compared who imported wheat. To that end, we have to change agricultural policy and bring it in line with the existing global challenges.

In the last two decades, there has been a trend towards the decline in world cereal output and the continuing rise in their prices. The latter is also due to the fact that population growth has far outpaced the per capita growth of cereal production.
In the last four decades, the global price of 1 ton of wheat has increased from $\$ 80.4$ to $\$ 173.4$. The era of cheap food in the world has come to an end.

Economic calculations indicate that by 2025 , the optimal area for wheat will be considered: 114.0 thousand ha, for crops - 421.8 thousand tons, for a grain-storing - 120.0 thousand ha, and for a fodder - 50.0 thousand ha, for maize - 170,0 thousand ha and 714,0 thousand tons, for barley 50,0 thousand ha and 160,0 thousand tons, for oats - 20,0 thousand ha and 50,0 thousand tons. In case of land consolidation, the wheat cultivation area may be increased to 150.0 thousand hectares.

In order to avoid the long-standing problem, it is necessary to apply all the reserves for increasing domestic cereal production, for which, first of all, Georgia should adopt a financially, technically, technologically and institutionally strong State program supporting grain producers, which will also involve institutional measures to produce elite seeds. 